\title{
Mental health impact of detention and temporary status for refugee claimants under Bill C-31
}

\author{
Janet Cleveland PhD, Cécile Rousseau MD
}

$\mathrm{T}$ he Canadian government is on the brink of adopting Bill C-31, the Protecting Canada's Immigration System Act, which could potentially have a serious negative impact on the mental health of refugees.

Bill C-31 gives the government the discretion to designate any group of two or more refugee claimants entering Canada as an "irregular arrival" if they are suspected of having obtained travel documents from smugglers or if normal processing would be too time-consuming. Refugees routinely rely on smugglers to escape their country, so many refugee claimants could potentially be affected. ${ }^{2}$

Designated refugee claimants will be automatically detained in high-security prisons until final resolution of their refugee claim; this would include pregnant women, survivors of torture or people who are mentally or physically ill. Designated claimants found to be bona fide refugees will be deprived of their right to family reunification and permanent residence for 5 years.

Children aged 16-18 years will be incarcerated as if they were adults. Those under 16 years of age will either be taken away from their parents and placed in foster care, or held informally with their detained mothers in an immigration prison. In both cases, they will be separated from their fathers.

The Canadian Paediatric Society, the Canadian Academy of Child and Adolescent Psychiatry, the Paediatric Chairs of Canada, and the Urban Public Health Network of Canada have urged the government to ensure that children are not placed in detention or separated from their parents in light of consistent evidence that both detention and separation are harmful to children. ${ }^{3}$ They have also asked that the government eliminate the 5-year postponement of permanent residence given the negative health consequences of lengthy family separation and prolonged uncertainty. ${ }^{46}$

Initially, there was to be no detention review for the first 12 months. In response to widespread criticism, the government is now proposing detention review after 14 days. This is a major improvement. However, the second detention review would only occur 6 months later. Therefore, those who are not released after the initial detention review would automatically be detained for an additional 6 months.

Bill C-31 was introduced following the arrival of 2 boats carrying Tamil refugee claimants. This bill has the declared aim of deterring human smugglers from facilitating irregular mass arrivals. However, the Canadian Bar Association stated:

Unfortunately, little of [the bill] is directed at smugglers. Instead, it is directed at refugee claimants and refugees... The [bill's] scheme of imposing imprisonment, denial of access to permanent resident status and loss of appeal rights on persons claiming protection violates Charter protections against arbitrary detention and prompt review of detention, as well as Canada's international obligations respecting the treatment of persons seeking protection. ${ }^{7}$

Under the existing laws, refugee claimants may be indefinitely detained upon arrival in Canada, primarily for identity or security checks. Most are held in immigration detention centres run as prisons, with razor-wire fences, security guards, surveillance cameras and handcuffing. Others are incarcerated in provincial prisons alongside criminals. Yet, less than $6 \%$ of detained refugee claimants are suspected of criminal activity or being a security risk. ${ }^{2}$ In the past five years, an average of over 650 children each year have been imprisoned in Canada under immigration laws. ${ }^{2}$

However, under the current system there are at least some safeguards. Few refugee claimants are detained, there are regular detention reviews by an independent tribunal, and claimants are
Competing interests: Janet Cleveland and Cécile Rousseau hold grant funding from the Canadian Institutes of Health Research.

This article has been peer reviewed.

Correspondence to: Janet Cleveland, janet.cleveland@mail .mcgill.ca

CMAJ 2012. DOI:10.1503 /cmaj.120282 
usually released as soon as identity and security checks are completed, generally within less than 3 months. $^{2}$ Bill C-31 would impose a much harsher regime.

Numerous studies have shown high levels of psychiatric symptoms among detained refugee claimants, even after short periods. ${ }^{8}$ Symptoms generally worsen over time. In the United Kingdom, after a median 30-day detention, $76 \%$ of detained refugee claimants were clinically depressed, compared with $26 \%$ of a nondetained comparison sample. ${ }^{9}$ In the United States, after a median detention of 5 months, $86 \%$ of refugee claimants showed clinical levels of depression, 77\% had clinical anxiety and 50\% had clinical post-traumatic stress disorder. A few months later, the mental health of those who were still detained had continued to deteriorate, whereas it had substantially improved among those who had been released and granted permanent status. ${ }^{10}$

The clearest evidence of the harm associated with long-term detention comes from Australia. Since 1992, all refugee claimants entering without a visa have been detained, until final resolution of their claim. In 2010/11, there were over 1100 incidents of self-harm in Australian immigration detention centres, including 6 suicides, ${ }^{11}$ in a population of about 6000 people detained for a median of 10 months. ${ }^{12}$ This is about 10 times the suicide rate in the general population in both Canada and Australia. ${ }^{13,14}$ Yet, in Australia, close to $90 \%$ of "irregular" claimants are later accepted as refugees and settle there permanently. ${ }^{15}$

In Australia, from 1999 to 2008, "irregular" arrivals recognized as genuine refugees received only temporary status. Australian researchers found that, 3 years after release, refugees who had been detained for more than 6 months and then granted temporary status were still very distressed, with half still experiencing clinical levels of both depression and post-traumatic stress disorder. Temporary status, which implies lengthy family separation and limited job access, was a strong predictor of depression and post-traumatic stress disorder, with an even larger negative impact than premigration trauma. ${ }^{4}$ Four years later, a followup study showed a substantial decrease in psychiatric symptoms among individuals who had finally obtained permanent residency. ${ }^{5}$

As health professionals, it is our responsibility to urge the government to minimize harm to children, pregnant women, trauma survivors and other vulnerable people. Children should not be incarcerated or separated from their parents. Detention of all refugee claimants should be lim- ited to the shortest possible time required for identity and security checks and should generally be in noncarceral accommodation, especially for vulnerable individuals. Ongoing oversight by an independent tribunal is an essential safeguard.

\section{References}

1. Bill C-31. An Act to amend the Immigration and Refugee Protection Act, the Balanced Refugee Reform Act, the Marine Transportation Security Act and the Department of Citizenship and Immigration Act, 41st Parliament, 1st Sess. (2011). Available: www.parl.gc.ca/HousePublications/Publication.aspx ?Docid $=5581460 \&$ file $=4$ (accessed 2012 June 1$)$.

2. Nakache D. The human and financial cost of detention of asylumseekers in Canada. Ottawa (ON); 2011. Available: www.sciences sociales.uottawa.ca/edim/fra/documents/DNakache-FINAL REPORT-December2011.pdf (accessed 2012 June 1).

3. Kronick R, Rousseau C, Cleveland J. Mandatory detention of refugee children in Canada: A public health issue? Paediatr Child Health 2011;16:e65-7.

4. Steel Z, Silove D, Brooks R, et al. Impact of immigration detention and temporary protection on the mental health of refugees. Br J Psychiatry 2006;188:58-64.

5. Nickerson A, Steel Z, Bryant R, et al. Change in visa status amongst Mandaean refugees: Relationship to psychological symptoms and living difficulties. Psychiatry Res 2011;187:267-74

6. Fazel M, Reed RV, Panter-Brick C, Stein A. Mental health of displaced and refugee children resettled in high-income countries: risk and protective factors. Lancet 2012;379:266-82.

7. Bill C-49. Preventing Human Smugglers from Abusing Canada's Immigration System Act. National Citizenship and Immigration Law Section of the Canadian Bar Association. Ottawa $(\mathrm{ON})$ : Canadian Bar Association; 2010. Available: www.cba.org/cba /submissions/pdf/10-78-eng.pdf (accessed 2012 Feb. 9).

8. Robjant K, Hassan R, Katona C. Mental health implications of detaining asylum seekers: systematic review. Br J Psychiatry 2009; 194:306-12.

9. Robjant K, Robbins I, Senior V. Psychological distress amongst immigration detainees: A cross-sectional questionnaire study. $\mathrm{Br} J$ Clin Psychol 2009;48:275-86.

10. Keller AS, Rosenfeld B, Trinh-Shevrin C, et al. Mental health of detained asylum seekers. Lancet 2003;362:1721-3.

11. Commonwealth of Australia Ombudsman Inquiry to examine suicide and self-harm in immigration detention. Canberra (AU); 2011. Available: www.ombudsman.gov.au/media-releases/show /189 (accessed 2012 Feb. 9).

12. Australian Government Department of Immigration and Citizenship. Immigration Detention Statistics Summary. Canberra (AU): The Department; 2011. Available: www.immi.gov.au/managing -australias-borders/detention/_pdf/immigration-detention-statistics -20111130.pdf (accessed 2012 Feb. 9).

13. Suicides and suicide rate, by sex and by age group, both sexes. Ottawa (ON): Statistics Canada; 2012. Available: www.statcan.gc .ca/tables-tableaux/sum-som/101/cst01/hlth66d-eng.htm (accessed 2012 June 1).

14. Australian Government Department of Health and Ageing. Living is for everyone. Fact sheet 3. Statistics on suicide in Australia. Canberra (AU): Commonwealth of Australia; 2011. Available: www.livingisforeveryone.com.au/IgnitionSuite /uploads/docs/LIFE\%20factsheet_3_web.PDF (accessed 2012 June 1).

15. Australian Government Department of Immigration and Citizenship. Refugee and humanitarian issues: Australia's response. Canberra (AU): Commonwealth of Australia; 2011. Available: www.immi.gov.au/media/publications/refugee/ref-hum-issues/pdf /refugee-humanitarian-issues-june11.pdf (accessed 2012 Feb. 9).

Affiliations: From the Research Institute of the McGill University Health Centre and Centre de recherche et de formation (Cleveland), Centre de santé et de services sociaux de la Montagne; and the Division of Social and Cultural Psychiatry (Rousseau), McGill University, Montréal, Que.

Contributors: Both of the authors contributed to the conception of the article. Janet Cleveland drafted the manuscript, which was substantially revised by Cécile Rousseau. Both authors approved the final version submitted for publication. 